\title{
Intravitreal Triamcinolone in Posterior Segment Diseases - Method of administration
}

\author{
TS Oluleye, ${ }^{1} \mathrm{O} \mathrm{Ajayi}^{2}$ \\ ${ }^{1}$ Retina Unit, Department of Ophthalmology, University College Hospital, Ibadan \\ ${ }^{2}$ Department of Ophthalmology, Obafemi Awolowo University Teaching Hospital, Ile-Ife
}

Triamcinolone is an intermediate-acting synthetic glucocorticoid-9 $\alpha$-Fluoro- $16 \alpha$-hydroxyprednisolone. It is five times more potent than hydrocortisone. ${ }^{1}$ It was approved by FDA and patented for the treatment of perennial and seasonal allergic rhinitis. Its mechanism of action includes multiple anti-inflammatory actions such as reduced fluid transudation, inhibition of anti-inflammatory cytokines and interference with fibroblast and endothelial cell function.

Intraocular pharmacological considerations include its minimally water-soluble suspension formulation, hence prolonged action and lack of tissue toxicity noted in animal and human studies. ${ }^{2}$

Recent developments have demonstrated the importance of triamcinolone in the management of ophthalmic conditions. Researchers and clinicians have shown its efficacy in the management of posterior segment diseases. ${ }^{3-10}$ It is readily available and cheap in Nigeria, hence the need for ophthalmic practitioners to be aware of its use and how to administer the medication appropriately.

Indications for intravitreal triamcinolone include primary treatment of macular oedema from diabetic retinopathy, retinal vein occlusion and posterior uveitis. It has also been found to be useful in cystoid macular oedema, idiopathic juxtafoveal telangiectasia and neovascular agerelated macular degeneration. ${ }^{3-10}$

\section{METHOD OF INTRAVITREAL ADMINISTRATION}

\section{Pre-injection Patient Selection and Evaluation}

The injection is contraindicated in patients with glaucoma, and better avoided in the presence of ocular surface infections such as blepharitis, conjunctivitis and stye. This will reduce the risk of endophthalmitis.

Anaesthesia: Topical anaesthesia is adequate, but for uncooperative patients, we give peribulbar anaesthesia in our centre.

Mydriasis: The pupil is dilated for indirect ophthalmoscopy before, during and after injection.

The procedure is an aseptic procedure; we administer the injection in the operating theatre in our centre.

\section{Requirements}

1. 1cc syringes - the insulin or tuberculin syringes can be used with a 25,26 or $27 \mathrm{G}$ needle

2. Vial of triamcinolone acetonide $-40 \mathrm{mg} / \mathrm{ml}$

3. Povidone iodine

4. Callipers

5. Indirect ophthalmoscope

\section{METHOD OF INJECTION}

1. Cleaning of periorbital skin with povidone iodine

2. Heavy lid speculum and topical povidone iodine $5 \%$ instillation

3. Use callipers to measure injection site from the limbus, at pars plana, $4 \mathrm{~mm}$ for phakics, $3.5 \mathrm{~mm}$ for pseudophakics and $3 \mathrm{~mm}$ for aphakics.

4. Withdraw triamcinolone suspension with insulin syringe and $21 \mathrm{G}$ needle.
a. Use fresh vial for injection.
b. Clean top of vial with povidone or spirit.
c. Shake vial well due to the suspension nature of triamcinolone.
d. Withdraw triamcinolone, and change needle to 25- $27 \mathrm{G}$ for injection

\section{Injecting triamcinolone}

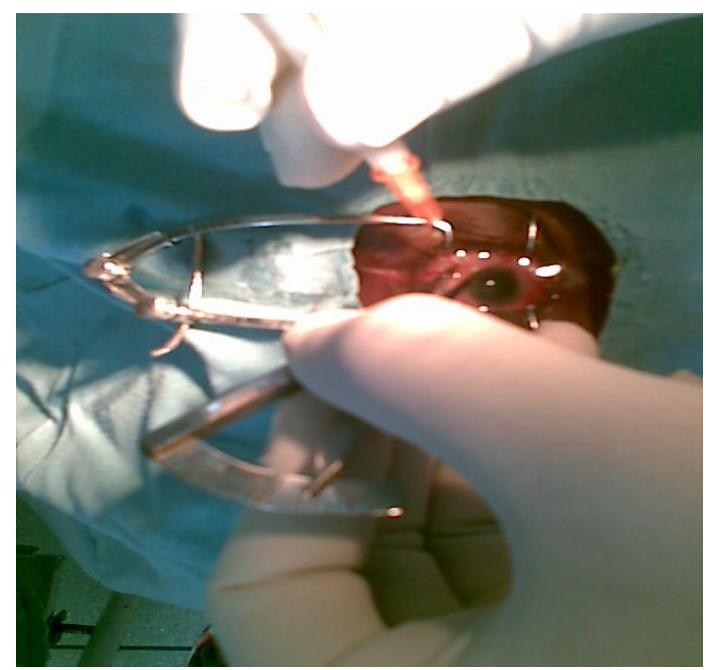

${ }^{*}$ Correspondence: Professor TS Oluleye, Retina Unit, Department of Ophthalmology, University College Hospital, Ibadan • Email: t_oluleye@yahoo.co.uk 
a. Cross-check calliper measurements at pars plana

b. Injection directed at the centre of vitreous cavity and optic nerve head

c. See the needle before injecting

d. Watch the lens in phakic patients

Apply cotton bud to injection site to prevent reflux.

Anterior chamber paracentesis is performed if digital IOP is high or arterial pulsation noted on indirect ophthalmoscopy.

a. Use 25-27G needle, cotton bud to stabilize the eye

b. Watch the lens in phakics

c. It is avoided in aphakics as vitreous will come to AC

Post-injection povidone iodine drops and indirect ophthalmoscopy are mandatory to check for arterial pulsation, a sign of optic nerve vascular compromise; if present, repeat paracentesis.

- Pad the eye overnight, patient is advised to assume a sitting position for the first $6 \mathrm{hrs}$ to avoid triamcinolone crystals settling on fovea.

- The intraocular pressure should be checked within 24 hours; follow up is then scheduled for one week, one month, three months and six monthly thereafter.

- Topical ciprofloxacin four times daily is recommended in the first week of injection.

\section{COMPLICATIONS OF INTRAVITREAL}

\section{TRIAMCINOLONE}

Complications associated with intravitreal triamcinolone have been documented. ${ }^{10}$ They are:

Drug-related
1. Elevated IOP
2. Endophthalmitis
3. Cataract

Injection-related

1. Retinal detachment

2. Traumatic cataract

3. Vitreous haemorrhage

\section{PREPARATION OF COMMON INTRAVITREAL}

\section{INJECTIONS}

1. Vancomycin

Dose: $1 \mathrm{mg}$ in $0.1 \mathrm{ml}$

- $500 \mathrm{mg}$ vial

- Add $5 \mathrm{mls}$ of saline

- $1 \mathrm{ml}=100 \mathrm{mg}$

- $0.1 \mathrm{ml}=10 \mathrm{mg}$, then make up to $1 \mathrm{ml},=10 \mathrm{mg}$, then take $0.1 \mathrm{ml}=1 \mathrm{mg}$

2.

\section{Ceftazidime}

Dose: $2-2.25 \mathrm{mg}$ in $0.1 \mathrm{ml}$

- $1000 \mathrm{mg}$ vial
- Add $10 \mathrm{mls}$ of saline

- Withdraw $0.1 \mathrm{ml}=10 \mathrm{mg}$

- Make up to $0.45 \mathrm{ml}$ with saline

- $\quad 0.45 \mathrm{ml}=10 \mathrm{mg}$

- $\quad 0.1 \mathrm{ml}=2.22 \mathrm{mg}$

3. Amphotericin B

Dose: 5 microgram $=0.5 \mathrm{mg}$ in $0.1 \mathrm{ml}$

- $50 \mathrm{mg}$ vial

- Add $10 \mathrm{mls}$ of saline

- $1 \mathrm{ml}=5 \mathrm{mg}$

- $\quad 0.1 \mathrm{ml}=0.5 \mathrm{mg}$

4. Amikacin

Dose: $0.4 \mathrm{mg}$ in $0.1 \mathrm{ml}$

- $500 \mathrm{mg} / \mathrm{ml}$ vial

- Withdraw $1 \mathrm{ml}$ (500mg), make up to $2 \mathrm{ml}$ with saline

- Withdraw $1.6 \mathrm{ml}=400 \mathrm{mg}$

- Add saline to make $10 \mathrm{mls}=40 \mathrm{mg} / \mathrm{ml}$

- Withdraw $1 \mathrm{ml}(40 \mathrm{mg})$ and make up to $10 \mathrm{mls}$ with saline $=4 \mathrm{mg} / \mathrm{ml}$

- $\quad 0.1 \mathrm{ml}$ of this $=0.4 \mathrm{mg}$

5. Gentamicin

Dose: $0.2 \mathrm{mg}$ in $0.1 \mathrm{ml}$

- $40 \mathrm{mg} / \mathrm{ml}$ vial

- Withdraw $0.5 \mathrm{ml}=20 \mathrm{mg}$

- $\quad$ Add saline to make $10 \mathrm{mls}=2 \mathrm{mg} / \mathrm{ml}$

- $\quad 0.1 \mathrm{ml}$ of this $=0.2 \mathrm{mg}(200 \mathrm{mcg})$

6. Bevacizumab (Avastin)

Dose: $0.05 \mathrm{ml}(1.25 \mathrm{mg})$

- $25 \mathrm{mg} / \mathrm{ml}$ vial

7. Ranibizumab (Lucentis)

Dose: $0.05 \mathrm{ml}$ ( 0.5mg)

- $10 \mathrm{mg} / \mathrm{ml}$ vial

8. Triamcinolone

Dose: $0.1 \mathrm{ml}(4 \mathrm{mg})$

- $40 \mathrm{mg} / \mathrm{ml}$ vial

9. Dexamethazone

Dose: $0.1 \mathrm{ml}(0.4 \mathrm{mg})$

- $4 \mathrm{mg} / \mathrm{ml}$

10. Ganciclovir

Dose: $2 \mathrm{mg}$ in $0.1 \mathrm{ml}$

- $500 \mathrm{mg}$ vial

- $\quad$ Add $10 \mathrm{mls}$ saline $=50 \mathrm{mg} / \mathrm{ml}$

- Withdraw $0.1 \mathrm{ml}(5 \mathrm{mg})$, make up to $0.25 \mathrm{ml}$ with saline

- $\quad 0.1 \mathrm{ml}$ of this $=2 \mathrm{mg}$. 


\section{REFERENCES}

1. McCuen BW, Bessler M, Tano Y, Chandler D, Machemer R. The lack of toxicity of intravitreally administered triamcinolone acetonide. Am J Ophthalmol 1981; 91: 785-8.

2. Jonas JB, Kreissig I, Sofker A, Degenring RF. Intravitreal injection of triamcinolone for diffuse diabetic macular edema. Arch Ophthalmol 2003; 121: 57-61.

3. Jonas JB, Akkoyun I, Kreissig I, et al. Diffuse diabetic macular edema treated by intravitreal triamcinolone acetonide: a prospective comparative non randomized study. $\mathrm{Br} J$ Ophthalmol 2005; 89: 321-6.

4. Massin P, Andren F, Haouchine B, et al. Intravitreal triamcinolone acetonide for diabetic diffuse macular edema: preliminary results of a prospective controlled trial. Ophthalmology 2004; 111: 218-24..

5. Sutter FKP, Simpson JM, Gillies MC. Intravitreal triamcinolone for diabetic macular edema that persists after laser treatment. Three month efficacy and safety results of a prospective randomized, double masked, placebo-controlled clinical trial. Ophthalmology 2004; 111: 2044-9.
6. Bardak Y, Cekic O, Tig SU. Comparison of ICG-assisted ILM peeling and triamcinolone-assisted posterior vitreous removal in diffuse diabetic macular edema. Eye 2006; 20: 1357-1359.

7. Penfold PL, Wen L, Madigan MC, et al. Triamcinolone acetonide modulates permeability and intercellular adhesion molecule-1 (ICAM-1) expression of the ECV304 cell line: implications for macular degeneration. Clin Exp Immunol 2000; 121: 458.

8. Spaide RF, Soronson J, Maranan L. Photodynamic therapy with verteporfin combined with intravitreal injection of triamcinolone acetonide for choroidal neovascularization. Ophthalmology 2005; 112: 301-304.

9. Young S, Larkin G, Branley M, Lightman S. Safety and efficacy of intravitreal triamcinolone for cystoid macular oedema in uveitis.Clin Experiment Ophthalmol 2001; 29: 2-6.

10. Jonas JB, Degenring RF, Kreissig I, et al. Intraocular pressure elevation after intravitreal triamcinolone acetonide injection. Ophthalmology 2005; 112: 593-598.

11. Moshfeghi DM, Kaiser PK, Scott IU, et al. Acute endophthalmitis following intravitreal triamcinolone acetonide injection. Am J Ophthalmol 2003; 136: 791-796. 